\title{
PROBLEMATIKA TATA CARA EKSEKUSI GANTI KERUGIAN DALAM PERKARA PIDANA
}

\author{
(Problematic Procedures of Remedy Enforcement in Criminal Cases)
}

\author{
Yuliyanto \\ Pusat Penelitian dan Pengembangan Hukum \\ Badan Penelitian dan Pengembangan Hukum dan HAM \\ Jl. H.R. Rasuna Said Kav. 4-5 Kuningan, Jakarta Selatan \\ Telp. (021) 2525015, Fax. (021) 2526678 \\ yuliyanto_oke@yahoo.com
}

Tulisan Diterima: 20 Juni 2019; Direvisi: 29 Agustus 2019; Disetujui Diterbitkan: 10 September 2019 DOI: http://dx.doi.org/10.30641/dejure.2019.V19.349-360

\begin{abstract}
There are still cases of wrongful arrests or procedural errors in criminal cases that cause innocent people have their rights prejudiced, therefore the Government must indemnify the prejudiced rights of the victims. This study addresses the issue of the procedures for the remedies that are considered fair for the victims of wrongful arrest. This study is descriptive analytic intended to reveal the real problem or situation or event in order to reveal the actual facts. Data are obtained from interviews, questionnaires, legislation and literature. Based on the results of the research, the followings are highly recommended: first, it is necessary to facilitate easy determination of the remedy, consequently the remedy determination process should be made quick. Judges need to determine the amount of the remedy payable by the State to the victims of wrongful arrest/wrongful procedures, so that victims do no longer need to initiate any claim for such remedy. Second, the payment mechanism, should remain be payable through the Ministry of Finance, in this regard, the Ministry of Finance needs to prepare guidelines for the purpose of accelerating the disbursement process of the determined remedy amount. As the currently applicable guidelines / regulations are still the Minister of Finance Regulation No. 983 / KMK.01 / 1983.
\end{abstract}

Keywords: : procedure; remedy; criminal case.

\begin{abstract}
ABSTRAK
Masih adanya kasus salah tangkap atau kesalahan prosedur dalam perkara pidana menyebabkan orang yang tidak bersalah harus terkurangi haknya, oleh sebab itu Pemerintah harus menggantikan hak dari korban yang terkurangi tersebut. Kajian ini menjawab permasalahan bagaimana tata cara eksekusi ganti kerugian yang dirasa adil bagi korban salah tangkap. Pengkajian ini bersifat deskriptif analitik yang ditujukan untuk mengungkapkan suatu masalah, keadaan atau peristiwa sebagaimana adanya sehingga dapat mengungkapkan fakta yang sebenarnya. Data diperoleh dari hasil wawancara, kuesioner, peraturan perundang-undangan dan literature. Dari hasil pengkajian direkomendasikan hal-hal sebagai berikut: pertama, perlu dipermudah pemberian ganti kerugian, oleh karena itu proses ganti kerugian ini lebih baik melalui proses yang cepat. Hakim perlu menetapkan besaran kerugian yang harus dibayarkan oleh Negara kepada korban salah tangkap/salah prosedur tersebut, sehingga korban tidak perlu lagi mengajukan gugatan ganti kerugian. Kedua, mekanisme pembayaran ganti kerugian, tetap harus dibayarkan melalui Kementerian Keuangan, terkait hal ini, Kementerian Keuangan perlu membuat pedoman dalam rangka mempercepat proses pencairan ganti kerugian. Karena pedoman/aturan yang ada saat ini masih menggunakan Peraturan Menteri Keuangan Nomor 983/KMK.01/1983.
\end{abstract}

Kata kunci: tata cara; ganti kerugian; perkara pidana. 


\section{PENDAHULUAN}

Kejadian salah tangkap, ditahan, dituntut dan diadili atau dikenakan tindakan lain, tanpa alasan yang berdasarkan undang-undang atau karena kekeliruan mengenai orangnya atau hukum yang diterapkan sudah lama menjadi perhatian pemerintah. Kejadian salah tangkap lebih sering terjadi jika dibandingkan dengan salah tuntut maupun salah diadili. Hal ini dapat dilihat dari beberapa kasus yang dihimpun oleh Tim, diantaranya: Tahun 2014, Kepolisian Resort Kudus juga melakukan salah tangkap, bahkan sampai melakukan penyiksaan dan pembakaran pada korban yang dipaksa untuk mengaku sebagai pelaku perampokan. ${ }^{1}$ Kemudian pada tahun 2017, anggota Kepolisian Sektor Tungkal Ilir Kabupaten Banyuasin juga melakukan kesalahan fatal, yaitu menembak kedua kaki Jailani karena dituduh melakukan pencurian dengan pemberatan, yang tidak pernah Jailani lakukan. Penembakan ini mengakibatkan kedua kaki Jailani tidak normal lagi. Selain ditembak, Jailani juga dikurung di Rumah Tahanan Polsek Tungkal Ilir, sampai pada putusan praperadilan yang dimohonkannya di Pengadilan Negeri Sekayu dikabulkan oleh hakim tunggal Christoffel Harianja, pada sidang putusan, Senin 30 Oktober $2017 .^{2}$

Berdasarkan data yang dirilis Lembaga Bantuan Hukum (LBH) Jakarta, pengaduan atas kasus salah tangkap hingga penyiksaan oleh oknum kepolisian dalam tiga tahun terakhir cukup tinggi, tercatat sebanyak 37 kasus yang dilaporkan. Pada April 2017, salah satu kasus salah tangkap itu dialami oleh tiga orang warga Tangerang bernama Aris, Bihin, dan Heryanto. Ketiganya diamankan polisi dari Subdit Jatanras, Direktorat Reserse Kriminal Umum Polda Metro Jaya atas kasus pencurian sepeda motor. ${ }^{3}$

1 Butje Tampi, "KUHAP Dan Pengaturan Ganti RugiPihak Korban Dalam Perkara Pidana," Vol.II/No.2/Januari-Maret $/ 2014$ Edisi Khusus II (2014): 24-35.

2 Republik Indonesia, Undang-Undang Nomor 8 Tahun 1981 Tentang Hukum Acara Pidana, 1981.

3 Abraham Utama, "Kisah Kuswanto, Korban Salah Tangkap Yang Dibakar Polisi," Cnn Indonesia, last modified 2015, accessed January 25, 2018, https://www.cnnindonesia.com/nasional/201506260
Salah satu upaya yang bisa dilakukan untuk memperoleh keadilan dengan menuntut ganti kerugian dan rehabilitasi. Dalam konteks peradilan pidana, hak setiap orang untuk menuntut ganti rugi kepada Negara karena ditangkap, ditahan, dituntut, dan diadili atau dikenakan tindakan lain tanpa alasan yang berdasarkan undang-undang atau karena kekeliruan mengenai orangnya atau hukum yang diterapkan sebagaimana diatur dalam Pasal 77 jo Pasal 95 Undang-Undang Nomor 8 Tahun 1981 tentang Hukum Acara Pidana (KUHAP). ${ }^{4}$

Selain kejadian salah tangkap, ada juga kejadian lambatnya proses pencairan ganti rugi, sebagaimana dialami oleh Andro dan Nurdin, korban salah tangkap. Andro dan Nurdin didampingi LBH Jakarta mengajukan permohonan sengketa non-litigasi peraturan perundangundangan di Kementerian Hukum dan Hak Asasi Manusia. Permohonan tersebut diajukan lantaran Peraturan Menteri Keuangan dinilai menghambat korban salah tangkap yang tidak kunjung menerima kompensasi. Padahal, hakim praperadilan memerintahkan negara memberikan ganti kerugian sebesar Rp 72 juta kepada Andro dan Nurdin. Tapi apa daya, putusan 9 Agustus 2016 itu belum dilaksanakan hingga hari ini. ${ }^{5}$

Perhatian pemerintah dilakukan dalam bentuk revisi Peraturan Pemerintah (PP), yang rencananya akan dilakukan revisi ketiga PP Nomor 27 Tahun 1983. Persoalan lain yang menjadi perhatian Pemerintah adalah mengenai tata cara eksekusi ganti kerugian. Tata cara eksekusi ganti kerugian harus melalui proses yang tidak mudah. Pengaturan tata cara pencairan dana masih berbeda, pada PP Nomor 92 tahun 2015 menyebutkan 14 hari sedangkan dalam mekanisme pencairan dana ganti kerugian yang diatur oleh Keputusan Menteri Keuangan Republik Indonesia Nomor 983/KMK.01/1983 tentang Tata Cara Pembayaran Ganti Kerugian masih belum memungkinkan untuk melakukan pencairan dana ganti kerugian dalam waktu 14 hari.

90000-32-62513/kisah-kuswanto-korban-salahtangkap-yang-dibakar-polisi..

4 Mewan Haqulana, "Kisah Korban Salah Tangkap, Dua Kaki Didor Oknum Polisi Sampai Pasrah Ingin Mati," Okezone.

5 Sherly Puspita, "Kisah Korban Salah Tangkap Yang Disiksa Polisi," Kompas.Com. 
Perkembangan tata cara eksekusi ganti kerugian di dalam PP Nomor 27 Tahun 1983 dan PP Nomor 92 Tahun 2015 bahwa ganti kerugian hanya dapat diawali dengan tuntutan, padahal Pasal 95 KUHAP tidak menentukan demikian.

Pada prakteknya masih ditemukan kesulitan-kesulitan dalam melakukan tuntutan ganti kerugian. Sebagai contoh, pada Putusan Nomor 98/Pid.Prap/2016/PN.Jaksel terdapat permasalahan yang menarik. Hakim mengabulkan tidak sampai setengah dari tuntutan ganti kerugian yang mereka terima, dan selain itu masih terdapat permasalahan dalam proses pencairan dana bagi korban salah tangkap tersebut belum dapat dilakukan karena terhambat mekanisme pencairan dana yang terdapat di dalam Peraturan Menteri Keuangan Republik Indonesia Nomor 983 /KMK.01.1983. Mengingat bahwa dalam PP Nomor 92 tahun 2015 yang menggantikan PP Nomor 27 tahun 1983 tentang pelaksanaan kitab Undang-Undang Hukum Acara Pidana, dimana dalam PP Nomor 92 tahun 2015 menyatakan pencairan dana ganti kerugian dilakukan selama 14 hari dan itu faktanya para korban salah tangkap sampai sekarang belum menerima ganti kerugian yang mereka anggap sesuai.

Pada prakteknya muncul permasalahan baru yaitu terdapat ketidakpastian hukum dalam hal proses pencairan ganti kerugian, dimana terjadi perbedaan antara peraturan menteri dengan peraturan pemerintah. Ketidakpastian itu terletak pada waktu lamanya pencairan dana ganti kerugian terhadap korban salah tangkap, mereka beranggapan untuk pencairan dana ganti kerugian harus melalui proses yang tidak mudah yang diatur dalam Keputusan Menteri Keuangan Republik Indonesia Nomor 983/KMK.01/1983 tentang Tata Cara Pembayaran Ganti Kerugian.

Permasalahan yang diangkat dalam pengkajian ini yaitu: Bagaimana tata cara eksekusi ganti kerugian yang dirasa adil bagi korban salah tangkap dalam perkara pidana? Tujuan dari pengkajian ini adalah untuk mengetahui dan menganalisis problematika eksekusi ganti kerugian yang dirasa adil bagi korban salah tangkap dalam perkara pidana.

\section{METODE PENELITIAN}

Pengkajian ini bersifat deskriptif analitis yang ditujukan untuk mengungkapkan suatu masalah atau keadaan atau peristiwa sebagaimana adanya sehingga dapat mengungkapkan fakta yang sebenarnya. ${ }^{6}$ Bahan hukum primer yang digunakan berupa peraturan perundang-undangan terkait tata cara eksekusi ganti kerugian, sedangkan bahan hukum sekunder berupa literatur, hasil pengkajian, dan jurnal, kemudian dari data yang diperoleh dianalisis secara kualitatif.

\section{PEMBAHASAN DAN ANALISIS}

Ganti kerugian telah diatur dalam Pasal 1 angka 22, Pasal 95 dan 96 KUHAP. Pada ketentuan pasal tersebut mengamanatkan bahwa putusan ganti kerugian dapat diputus melalui sidang praperadilan. Namun selama ini korban dalam perkara ganti kerugian enggan untuk menuntut haknya, karena korban salah tangkap dalam perkara pidana adalah orang-orang "kecil" yang kurang memahami proses peradilan. Untuk itu, perlu adanya suatu terobosan yang memudahkan para korban ini untuk mendapatkan hak ganti kerugian.

Turunan peraturan dari Pasal 95 dan 96 KUHAP adalah PP Nomor 27 Tahun 1983 tentang Pelaksanaan Kitab Undang Undang Hukum Acara Pidana dan PP Nomor 92 Tahun 2015 tentang Perubahan Kedua atas PP Nomor 27 Tahun 1983. Untuk lebih jelasnya mengenai perkembangan tata cara eksekusi ganti kerugian, dapat dilihat pada tabel berikut:

Tabel 1. Perkembangan Tata Cara Eksekusi Ganti Kerugian

\begin{tabular}{|c|c|}
\hline $\begin{array}{c}\text { PP Nomor } 27 \text { Tahun } \\
1983 \text { tentang } \\
\text { Pelaksanaan Kitab } \\
\text { Undang Undang Hukum } \\
\text { Acara Pidana } \\
\end{array}$ & $\begin{array}{l}\text { PP Nomor } 92 \text { Tahun } \\
2015 \\
\text { tentang Perubahan } \\
\text { Kedua atas PP Nomor } \\
27 \text { Tahun } 1983\end{array}$ \\
\hline $\begin{array}{l}\text { Tuntutan ganti kerugian } \\
\text { sebagaimana dimaksud } \\
\text { dalam Pasal 95 KUHAP } \\
\text { hanya dapat diajukan } \\
\text { dalam tenggang waktu } 3 \\
\text { (tiga) bulan sejak putusan } \\
\text { pengadilan mempunyai } \\
\text { kekuatan hukum tetap. }\end{array}$ & $\begin{array}{l}\text { Tuntutan ganti kerugian } \\
\text { sebagaimana dimaksud } \\
\text { dalam Pasal } \\
\text { KUHAP hanya dapat } \\
\text { diajukan dalam waktu } \\
\text { paling lama } 3 \text { (tiga) bulan } \\
\text { terhitung sejak tanggal } \\
\text { petikan atau salinan } \\
\text { putusan pengadilan yang } \\
\text { telah memperoleh } \\
\begin{array}{l}\text { kekuatan hukum tetap } \\
\text { diterima. }\end{array}\end{array}$ \\
\hline
\end{tabular}

6 Andi Saputra, "Ganti Rugi Tak Kunjung Cair, Korban Salah Tangkap Gugat Menkeu," DetikNews. 


\begin{tabular}{|c|c|}
\hline $\begin{array}{c}\text { PP Nomor } 27 \text { Tahun } \\
1983 \text { tentang } \\
\text { Pelaksanaan Kitab } \\
\text { Undang Undang Hukum } \\
\text { Acara Pidana }\end{array}$ & $\begin{array}{c}\text { PP Nomor } 92 \text { Tahun } \\
2015 \\
\text { tentang Perubahan } \\
\text { Kedua atas PP Nomor } \\
27 \text { Tahun } 1983\end{array}$ \\
\hline $\begin{array}{l}\text { Dalam hal tuntutan ganti } \\
\text { kerugian tersebut diajukan } \\
\text { terhadap perkara yang } \\
\text { dihentikan pada tingkat } \\
\text { penyidikan atau tingkat } \\
\text { penuntutan sebagaimana } \\
\text { dimaksud dalam Pasal } 77 \\
\text { huruf b KUHAP, maka } \\
\text { jangka waktu } 3 \text { (tiga) } \\
\text { bulan dihitung dari saat } \\
\text { pemberitahuan penetapan } \\
\text { praperadilan. }\end{array}$ & $\begin{array}{l}\text { Dalam hal tuntutan ganti } \\
\text { kerugian tersebut diajukan } \\
\text { terhadap perkara yang } \\
\text { dihentikan pada tingkat } \\
\text { penyidikan atau tingkat } \\
\text { penuntutan sebagaimana } \\
\text { dimaksud dalam Pasal } 77 \\
\text { huruf b KUHAP, maka } \\
\text { jangka waktu 3 (tiga) } \\
\text { bulan dihitung dari saat } \\
\text { tanggal pemberitahuan } \\
\text { penetapan praperadilan. }\end{array}$ \\
\hline $\begin{array}{l}\text { Petikan penetapan } \\
\text { mengenai ganti kerugian } \\
\text { sebagaimana diberikan } \\
\text { kepada pemohon dalam } \\
\text { waktu } 3 \text { (tiga) hari setelah } \\
\text { penetapan diucapkan. }\end{array}$ & $\begin{array}{l}\text { Petikan putusan atau } \\
\text { penetapan mengenai ganti } \\
\text { kerugian diberikan kepada } \\
\text { pemohon dalam waktu } 3 \\
\text { (tiga) hari setelah putusan } \\
\text { diucapkan. }\end{array}$ \\
\hline $\begin{array}{l}\text { Salinan penetapan ganti } \\
\text { kerugian diberikan kepada } \\
\text { penuntut umum, penyidik } \\
\text { dan Direktorat Jenderal } \\
\text { Anggaran. }\end{array}$ & $\begin{array}{l}\text { Petikan putusan atau } \\
\text { penetapan ganti kerugian } \\
\text { diberikan kepada penuntut } \\
\text { umum, penyidik, dan } \\
\text { Menteri yang } \\
\text { menyelenggarakan urusan } \\
\text { pemerintahan di bidang } \\
\text { keuangan. }\end{array}$ \\
\hline $\begin{array}{l}\text { Pembayaran ganti } \\
\text { kerugian dilakukan oleh } \\
\text { Menteri Keuangan } \\
\text { berdasarkan penetapan } \\
\text { pengadilan. }\end{array}$ & $\begin{array}{l}\text { Pembayaran ganti } \\
\text { kerugian dilakukan oleh } \\
\text { Menteri yang } \\
\text { menyelenggarakan urusan } \\
\text { pemerintahan di bidang } \\
\text { keuangan berdasarkan } \\
\text { petikan putusan atau } \\
\text { penetapan pengadilan. }\end{array}$ \\
\hline $\begin{array}{l}\text { Tata cara pembayaran } \\
\text { ganti kerugian diatur lebih } \\
\text { lanjut oleh Menteri } \\
\text { Keuangan. }\end{array}$ & $\begin{array}{l}\text { Pembayaran ganti } \\
\text { kerugian dilakukan dalam } \\
\text { jangka waktu paling lama } \\
14 \text { (empat belas) hari } \\
\text { kerja terhitung sejak } \\
\text { tanggal permohonan ganti } \\
\text { kerugian diterima oleh } \\
\text { Menteri yang } \\
\text { menyelenggarakan urusan } \\
\text { pemerintahan di bidang }\end{array}$ \\
\hline
\end{tabular}

\begin{tabular}{|c|c|}
\hline $\begin{array}{c}\text { PP Nomor } 27 \text { Tahun } \\
1983 \text { tentang } \\
\text { Pelaksanaan Kitab } \\
\text { Undang Undang Hukum } \\
\text { Acara Pidana }\end{array}$ & $\begin{array}{c}\text { PP Nomor } 92 \text { Tahun } \\
2015 \\
\text { tentang Perubahan } \\
\text { Kedua atas PP Nomor } \\
27 \text { Tahun } 1983\end{array}$ \\
\hline & $\begin{array}{l}\text { keuangan. } \\
\text { Ketentuan mengenai tata } \\
\text { cara pembayaran ganti } \\
\text { kerugian diatur dengan } \\
\text { Peraturan Menteri yang } \\
\text { menyelenggarakan urusan } \\
\text { pemerintahan di bidang } \\
\text { keuangan. }\end{array}$ \\
\hline
\end{tabular}

Tabel diolah oleh Penulis.

Berdasarkan tabel tersebut diketahui bahwa ganti kerugian hanya dapat diawali dengan tuntutan, artinya bahwa ganti kerugian harus diawali dengan tuntutan terlebih dahulu, padahal Pasal 95 KUHAP tidak menentukan demikian.

Selengkapnya Pasal 95 Ayat (1) menentukan bahwa tersangka, terdakwa atau terpidana berhak menuntut ganti kerugian karena ditangkap, ditahan, dituntut dan diadili atau dikenakan tindakan lain, tanpa alasan yang berdasarkan undang-undang atau karena kekeliruan mengenai orangnya atau hukum yang diterapkan.

\section{A. Definisi Tata Cara Eksekusi Ganti Kerugian}

Tata cara adalah aturan (cara) menurut adat kebiasaan. Eksekusi adalah pelaksanaan putusan hakim. Untuk itu dalam pengkajian ini yang dimaksud tata cara eksekusi adalah cara pelaksanaan kekuasaan untuk mendapat pemenuhan atas tuntutannya yang berupa imbalan sejumlah uang karena ditangkap, ditahan, dituntut ataupun diadili tanpa alasan yang berdasarkan undang-undang atau karena kekeliruan mengenai orangnya atau hukum yang diterapkan, sebagaimana yang telah disebutkan dalam KUHAP. Tata hukum atau kerap kali disebut hukum positif adalah hukum yang berlaku di suatu tempat dan pada saat tertentu (sekarang). Tata hukum di Indonesia adalah hukum yang sedang 
berlaku dewasa ini di Indonesia, baik hukum publik maupun hukum privat. ${ }^{7}$

Menurut Syafruddin ada dua cara pemberian ganti kerugian yang berkembang dewasa ini, yaitu: ${ }^{8}$

\section{1) Prosedural rights model}

Model ini menghendaki diikutsertakannya korban dalam proses peradilan, baik terlibat langsung dalam sidang pengadilan ataupun di belakang sidang diberikan ikut mempertimbangkan sanksi yang akan dijatuhkan pada pelaku tindak pidana. Model ini sangat menghambat kelancaran proses peradilan yang dikehendaki yaitu cepat tepat adil dan biaya ringan.

\section{2) Service model}

Model ini bersifat modern, karena memasukkan sanksi ganti kerugian ke dalam hukum pidana, ganti kerugian menjadi bagian hukum pidana, dan telah memperhatikan perbuatan, pelaku dan korban (daad-dader straftrecht dan victim).

Penggantian kerugian juga dapat dilakukan berdasarkan:

1) Putusan pengadilan;

2) Dilakukan di luar pengadilan.

Jika terjadi kesepakatan damai di antara para pihak yang terlibat dengan catatan kerugian tersebut terjadi pada kecelakaan lalu lintas ringan. Mekanisme korban memperoleh ganti kerugian dapat pula dilakukan melalui jalur non litigasi yaitu penyelesaian sengketa di luar pengadilan (non litigasi), yang lazim dinamakan dengan Alternative Dispute Resolution (ADR) atau Alternatif Penyelesaian Sengketa. Mediasi penal merupakan salah satu bentuk dari pelaksanaan restorative justice, yaitu konsep yang memandang kejahatan secara lebih luas. Konsep ini memandang bahwa kejahatan atau tindak pidana bukanlah hanya sekedar urusan pelaku tindak pidana dengan negara yang mewakili korban, dan meninggalkan proses penyelesaiannya hanya kepada pelaku dan negara (Jaksa Penuntut Umum). Praktik mediasi penal dalam memyelesaikan perkara pidana tertentu, baik yang dilakukan oleh sebagian anggota masyarakat dengan cara

7 Hadari Nawawi, Metode Penelitian Sosial (Yogyakarta: Gajahmada Press, 1993), 31.

8 Agus Sudaryanto, Pengantar Ilmu Hukum, Pengertian Dan Perkembangannya Di Indonesia (Malang: Setara Press, 2015), 18. perdamaian antara pelaku dan korban yang diakhiri dengan pembayaran ganti kerugian kepada korban.

Dalam mengimplementasikan peraturan ganti rugi harus mengutamakan kepentingan yang diatur dan bukan kepentingan yang mengatur. Harus diusahakan jangan sampai ada manipulasi peraturan demi kepentingan pribadi. Jadi harus dicegah pengorbanan struktural atas dasar suatu ketentuan peraturan perundang-undangan mengenai ganti rugi. Terutama yang harus dicegah adanya pengorbanan golongan lemah mental, fisik, sosial demi golongan kuat atau berkuasa. Misalnya, tidak dibayarnya ganti rugi, dipotongnya sebagian ganti rugi. ${ }^{9}$

\section{B. Pelaksanaan Ganti Kerugian dalam Perkara Pidana}

Pengaturan tata cara eksekusi ganti kerugian telah diatur dalam KUHAP, namun dalam pelaksanaannya masih belum terimplementasi dengan baik, terbukti dengan masih adanya korban salah tangkap yang belum terbayarkan haknya. Oleh karena itu, penulis mencoba mengulas Pasal yang mengatur tata cara eksekusi ganti kerugian tersebut.

Dalam menetapkan dikabulkan atau tidaknya tuntutan ganti kerugian adalah harus berdasarkan pertimbangan hakim atas kebenaran dan keadilan, sehingga tidak semua tuntutan ganti kerugian akan dikabulkan oleh hakim. ${ }^{10}$

Pada Pasal 77 KUHAP menyebutkan bahwa Pengadilan Negeri berwenang untuk memeriksa dan memutus, sesuai dengan ketentuan yang diatur dalam undang-undang ini tentang:

a) sah atau tidaknya penangkapan, penahanan, penghentian penyidikan atau penghentian penuntutan;

b) ganti kerugian dan atau rehabilitasi bagi seorang yang perkara pidananya dihentikan pada tingkat penyidikan atau penuntutan.

9 Syafruddin, Pidana Ganti Rugi: Alternatif Pemidanaan Di Masa Depan Dalam Penanggulangan Kejahatan Tertentu (Medan: Universitas Sumatera Utara, 2002), 6.

10 Flora Veronika, "Penerapan Ganti Kerugian Terhadap Terdakwa Yang Diputus Bebas Berdasarkan Kitab Undang-Undang Hukum Acara Pidana Di Pengadilan Negeri Pekanbaru," JOM Fakultas Hukum Volume III Nomor 1, Februari 2016. III (2016): 1-16. 
Berdasarkan Pasal 77 KUHAP di atas, Pengadilan dapat langsung memutus, ganti kerugian tanpa adanya tuntutan terlebih dahulu dari tersangka, terdakwa atau terpidana yang ditangkap, ditahan, dituntut dan diadili atau dikenakan tindakan lain, tanpa alasan yang berdasarkan undang-undang atau karena kekeliruan mengenai orangnya atau hukum yang diterapkan. Dari hasil survey menyatakan bahwa sebagian besar responden menyatakan setuju jika Pengadilan langsung memutus ganti kerugian yang harus dibayarkan oleh Pemerintah, dengan alasan supaya proses lebih cepat, sehingga korban dapat segera mendapatkan haknya. Informan juga menyatakan bahwa tidak diperlukan lagi gugatan untuk menuntut ganti kerugian yang timbul, sebab kerugian tersebut sudah nampak pada saat pemeriksaan perkara yang sehingga dalam sidang selain mengungkap pokok perkara juga mengungkap kerugian terdakwa secara nyata, selain itu putusan hakim juga tidak hanya berisi dengan pokok perkara namun juga penetapan ganti kerugian atau pemulihan terdakwa dari pokok perkara. Selain alasan tersebut, penetapan dalam putusan hakim tanpa penuntutan juga merupakan faktor yang dapat memberi efek pada para aparat penegak hukum untuk berhati-hati dalam memproses perkara.

Hal ini sejalan dengan pendapat Syafrudin bahwa tata cara ganti kerugian, dengan mengikutsertakan korban dalam proses peradilan, baik terlibat langsung dalam sidang pengadilan ataupun di belakang sidang diberikan ikut mempertimbangkan sanksi yang akan dijatuhkan pada pelaku tindak pidana. Model ini sangat menghambat kelancaran proses peradilan yang dikehendaki yaitu cepat tepat adil dan biaya ringan. Hal ini juga dikuatkan oleh pendapat Sri Sutatiek, bahwa putusan yang dihasilkan oleh hakim merupakan putusan pengadilan yang berkualitas, dengan catatan jika putusan hakim itu merupakan putusan yang dapat dipertanggungjawabkan bukan saja dari sisi dan aspek kepastian hukum (rumusan pasal-pasal dalam undang-undang) dan kemanfaatan bagi para pihak semata tetapi juga mencerminkan keadilan dan nilai-nilai kemanusiaan. ${ }^{11}$

Dalam hal terdapat kerugian, putusan pengadilan pidana harus sekaligus mencantumkan ganti kerugiannya. Sebagai putusan pengadilan, apabila telah berkekuatan hukum tetap maka negara dalam hal ini Jaksa Penuntut Umum (JPU) sebagai eksekutor segera menjalankannya. Hal ini dikuatkan oleh pendapat informan bahwa sesuai dengan bunyi undang-undang dan sudah menjadi hak tersangka, terdakwa, atau terpidana untuk langsung diganti kerugiannya oleh negara melalui jaksa penuntut umum selaku eksekutor, karena tidak sedikit korban yang tidak mengetahui proses peradilan pidana, sehingga mereka tidak tahu akan hak-haknya yang menyangkut ganti rugi. Selain itu, juga agar ada kepastian hukum bagi masyarakat yang dirugikan, kemudian teknis pencairan pembayaran ganti kerugian juga harus diputuskan. Ada informan yang berpendapat agar anggaran ganti kerugian ditempatkan di anggaran pengadilan, kepolisian atau kejaksaan. Tapi ada juga informan yang berpendapat anggaran pembayaran ganti kerugian itu ditempatkan di Kementerian Keuangan. Pembayaran ganti kerugian harus sesuai dengan asas peradilan, diselenggarakan secara cepat, sederhana dan biaya ringan sesuai dengan prinsip jaminan kepastian hukum bagi para pihak yang berpidana. Lemahnya kesadaran hukum masyarakat baik oleh masyarakat umum, masyarakat yang berperkara akan menciptakan ketidaktaatan terhadap hukum itu sendiri. Terkait dengan peradilan, maka masyarakat tersebut akan melakukan tindakantindakan yang melanggar hukum guna dapat memenangkan perkara atau setidaknya dapat mempengaruhi putusan pengadilan. ${ }^{12}$

Dalam hal pelanggaran prosedur penegakan hukum, baik yang masuk ke ranah hukum pidana maupun sekedar pelanggaran prosedur, diperlukan suatu keputusan hukum untuk

11 Sri Sutatiek, Menyoal Akuntabilitas Moral Hakim Pidana Dalam Memeriksa, Mengadili, Dan Memutus Perkara (Yogyakarta: Aswaja, 2013), 29.

12 Dahlan Sinaga, Kemandirian Dan Kebebasan Hakim Memutus Perkara Pidana Dalam Negara Hukum Pancasila, Suatu Perspektif Teori Keadilan Bermartabat (Bandung: Nusa Media, 2015), 278279. 
menjadi dasar dijatuhkannya ganti kerugian. Atas dasar itulah timbul kewajiban negara untuk memberikan ganti kerugian. Keputusan hukum, baik berupa suatu penetapan, putusan pengadilan, dan atau bentuk lainnya, harus bersifat final dan mengikat sehingga tidak dperlukan lagi upaya hukum apapun untuk menjalankannya kecuali sekedar ketentuan dan syarat administrasi sehubungan dengan birokrasi.

Korban pelanggaran prosedur penegakan hukum berada pada posisi lemah dan memerlukan mekanisme/tata cara peradilan yang sederhana dan pasti untuk menuntut haknya. Demi penjaminan hak tersangka, terdakwa, maka pelaksanaan putusan atau penetapan harus segera dilaksanakan demi memulihkan keadaan tersangka, terdakwa ke arah yang lebih baik, karena bila putusan hukum itu tidak bersifat final maka artinya masih terdapat upaya hukum yang dilakukan atas putusan tersebut, dan hal itu membutuhkan waktu yang terlalu lama. Sedangkan keadaan terdakwa mungkin akan lebih buruk apabila tidak dipenuhi pemulihannya dengan segera.

Mekanisme ganti kerugian korban karena ditangkap, ditahan, dituntut dan diadili atau dikenakan tindakan lain, tanpa alasan yang berdasarkan undang-undang atau karena kekeliruan mengenai orangnya atau hukum yang diterapkan, sebagaimana yang tertuang dalam KUHAP Pasal 95 angka (1), dapat dilakukan melalui penyelesaian sengketa di luar pengadilan (non litigasi), yang lazim dinamakan dengan Alternative Dispute Resolution (ADR). Karena model mediasi penal seperti ADR, Restorative Justice (RJ) sudah mulai dikembangkan dalam hukum pidana dan hukum acara pidana yang tujuannya untuk memperoleh keadilan dan keseimbangan, bukan pembalasan. Dengan ADR proses dapat lebih cepat dan dapat memangkas birokrasi. Selain itu juga agar proses pemberian ganti kerugian bisa berjalan cepat dan segera, sehingga orang yang kena kerugian dapat segera mendapatkan haknya. ADR dapat dilakukan demi mempercepat pemulihan hak tersangka, terdakwa. Namun dalam proses tersebut terhadap hasil penyelesaian di luar pengadilan juga harus sesuai dengan limitasi besaran yang ditetapkan oleh undang-undang, serta hasil tersebut ditetapkan dalam penetapan hakim agar memiliki kepastian hukum yang mengikat. Apabila nanti ganti kerugian tidak sesuai dengan apa yang ditetapkan oleh undang-undang maka hakim dapat menolak hasil penyelesaian di luar pengadilan tersebut dan memerintahkan untuk melakukan proses ADR dengan hasil yang besarnya ganti kerugian sesuai dengan undang-undang. Penyelesaian sengketa melalui ADR yang didasarkan pada kesepakatan para pihak, tidak secara otomatis memberikan daya paksa (kekuatan mengikat) bagi para pihak, akan tetapi hanya didasarkan pada itikad baik. ${ }^{13}$ Oleh karena itu, dalam penyelesaian sengketa melalui ADR harus dilandasi dengan rasa sukarela (tanpa paksaan).

Selain itu, ada informan yang berpendapat beda, bahwa pelanggaran hukum acara pidana masuk dalam ranah hukum publik (hubungan antara individu dengan negara) yang penyelesaiannya tidak dapat diserahkan pada kesepakatan antara korban dengan pelaku. Keputusan dalam proses peradilan dituangkan dalam putusan hakim atau putusan peradilan. Menurut Pasal 1 angka 11 KUHAP yang dimaksud dengan putusan hakim atau putusan peradilan adalah pernyataan hakim yang diucapkan dalam sidang pengadilan terbuka, yang dapat berupa pemidanaan atau bebas atau lepas dari segala tuntutan hukum dalam hal serta menurut tata cara yang diatur dalam undang-undang ini. Sedangkan menurut Lilik Mulyadi, yang dimaksud dengan putusan hakim adalah putusan yang diucapkan oleh hakim karena jabatannya dalam persidangan perkara pidana yang terbuka untuk umum setelah melalui proses dan prosedural hukum acara pidana pada umumnya berisikan pemidanaan atau bebas atau pelepasan dari segala tuntutan hukum yang dibuat dalam bentuk tertulis dengan tujuan menyelesaikan perkara. ${ }^{14}$

Terhadap pejabat yang karena kesalahan, kealpaan atau kelalaiannya mengakibatkan negara harus membayar ganti kerugian, dapat dikenakan tindakan sesuai dengan peraturan yang berlaku. Sesuai dengan asas peradilan diselenggarakan secara cepat, sederhana dan biaya ringan dan sesuai dengan prinsip jaminan kepastian hukum bagi para pihak yang berpidana. Supaya pejabat/aparat penegak hukum tidak sewenangwenang sendiri dalam hal bertindak, sebab segala perbuatan wajib dipertanggungjawabkan, baik kepada korban atau keluarga, masyarakat serta Negara. Pemberian sanksi terhadap pejabat/aparat penegak hukum yang melakukan kesalahan prosedur menjadikan public aware bagi penegak

13 Nevey Varida Ariani, "Gugatan Sederhana Dalam Sistem Peradilan Pidana Di Indonesia,” DE JURE 18 (2018): 381-396.

14 Lilik Mulyadi, Putusan Hakim Dalam Hukum Acara Pidana (Bandung: Citra Aditya Bakti, 2007), 121. 
hukum agar hati-hati dan lebih profesional dalam menjalankan kewenangannya. Penegak hukum yang melanggar hukum dipandang sama dengan masyarakat yang melanggar hukum, equality before the law. Hal tersebut menjadikan pembelajaran dan menciptakan upaya pencegahan bagi aparat penegak hukum untuk menerapkan hukum secara menyimpang serta membuat aparat penegak hukum untuk bersikap hati-hati dan mematuhi prosedur hukum yang berlaku demi menjamin hak terdakwa terpenuhi.

\section{Model Pemberian Ganti Kerugian di beberapa Negara}

\section{Amerika Serikat}

Kompensasi terhadap salah tangkap di Amerika Serikat diatur dalam Criminal Justice Act Section 1988 Section 133 yang hampir identik dengan International Covenant on Civil and Political Rights 1966 (ICCPR) Article 14 (6) dan European Convention on Human Rights (1984) (ECHR) Article 3 dari Protocol 7 yang berbunyi sebagai berikut: ${ }^{15}$

(1)...when a person has been convicted of a criminal offence and when subsequently his conviction has been reversed or he has been pardoned on the ground that a new or newly discovered fact shows beyond reasonable doubt that there has been a miscarriage of justice, the Secretary of State shall pay compensation for the miscarriage of justice to the person who has suffered punishment as a result of such conviction or, if he is dead, to his personal representatives, unless the non-disclosure of the unknown fact was wholly or partly attributable to the person convicted.

Dimana dapat diambil pengertian bahwa apabila seseorang telah dijatuhkan pidana dan dapat dibuktikan bahwa terhadap seseorang tersebut telah terjadi ketidakadilan, maka Negara harus membayar kompensasi kepada seseorang yang telah menjalani hukuman yang salah dijatuhkan, atau apabila seseorang itu telah mati,

15 Prancis, Protocol No.7 to the Convention for the Protection of Human Rights and Fundamental Freedoms (Perancis, 1984). Article 3 maka kompensasi akan diberikan kepada wakil dari orang tersebut. ${ }^{16}$ Seseorang dapat diberikan kompensasi sebesar $\$ 50,000$ per tahun atas kesalahan penjatuhan pidana penjara, sampai dengan $\$ 100,000$ per tahun atas kesalahan pidana hukuman mati. ${ }^{17}$

\section{Jepang}

Dalam Konstitusi Jepang yang dirancang setelah Perang Dunia II di bawah penjajahan Amerika Serikat, tertulis dalam Article 40 yang berbunyi:

"Any person, in case he is acquitted after he has been arrested or detained, may sue the State for redress as provided by law" 18

Dapat dikatakan bahwa seseorang memiliki hak untuk menuntut Negara dalam mendapatkan kompensasi seandainya dia menjadi korban salah tangkap. Mengenai kompensasi dalam Article 40 tersebut diatur lebih lanjut dalam the Criminal Compensation Act tahun 1950. The Criminal Compensation Act tahun 1950 merupakan peraturan yang berlaku di Amerika Serikat yang diadopsi oleh Jepang.

Dalam Article 4 the Criminal Compensation Act (1950) menyatakan bahwa besarnya kompensasi yang diberikan akan ditentukan oleh pengadilan. Pengadilan akan menentukan estimasi kompensasi yang diberikan dengan mempertimbangkan bagaimana korban salah tangkap ditahan, kerugian materil yang didapat, penderitaan fisik dan mental yang dialami, dan kerugian karena kelalaian polisi dan jaksa. Estimasi besarnya kompensasi yang diberikan

16 Hannah Quick and Marny Requa, "The Supreme Court on Compensation for Miscarriages of Justice: Is It Better That Ten Innocents Are Denied Compensation than One Guilty Person Receives It?," The Modern Law Review 75 (2012): 387-400, //www.jstor.org/stable/41682857.

17 Meghan Keneally, "Will the State Pay You for a Wrongful Conviction?," https://abcnews.go.com/US/state-pay-wrongfulconviction-depends-state/story?id=62436623.

18 Prime Minister of Japan and his Cabinet, The Constitution of Japan, 1947, https://japan.kantei.go.jp/constitution_and_governm ent_of_japan/constitution_e.html. 
untuk korban salah tangkap minimal JP¥1,000 setiap harinya yang dihitung selama korban salah tangkap tersebut ditahan. Sedangkan jumlah maksimal yang diberikan JP¥12,500. Seperti yang terjadi kepada Govinda Mainali yang dipenjara karena dituduh membunuh wanita Jepang. Govinda Mainali dibebaskan setelah 15 tahun dipenjara dan diberi ganti rugi sebesar JP¥68,000,000. ${ }^{19}$

Korban salah tangkap dapat mengajukan gugatan terhadap negara berdasarkan the State Redress Act (Act No. 125 of 1947). Namun, penggugat harus dapat membuktikan bahwa pejabat yang berwenang atau menjalankan tugasnya itu secara tidak sah menyebabkan kerugian pada orang lain dengan sengaja atau lalai dalam menjalankan tugasnya sebagaimana dikutip dalam Art. 1 of the Redress Act. ${ }^{20}$

\section{Belanda}

The Dutch Code of Civil akan memberikan kompensasi finansial untuk waktu yang telah dihabiskan oleh tersangka dalam praperadilan ketika kasus pidana tersebut berakhir tanpa adanya hukuman atau dengan hukuman pelanggaran yang mana tidak diterima dalam praperadilan. Kompensasi dimungkinkan juga untuk penahanan yang tidak sah, tetapi dalam retrospeksi untuk penahanan yang tidak sah dan juga tidak adil dalam prosesnya. Kompensasi disini tidak harus bersifat finansial. Penahanan yang melanggar hukum dan tidak sah dapat dikompensasikan dalam bentuk pengurangan durasi hukuman penjara yang dijatuhkan untuk pelanggaran pidana lainnya. Penahanan yang sah secara hukum tetapi pada akhirnya tidak bersalah akan dikompensasikan dengan pembayaran untuk perampasan kebebasan sebanyak Dfl. 100 sampai 150 per hari. Keputusan mengenai kompensasi ini berdasarkan prosedur pidana yang diberikan oleh pengadilan dan juga di depan kamera. Pengadilan ini akan terdiri dari hakim yang juga bertindak sebagai hakim persidangan kompensasi tersebut. ${ }^{21}$

Mengenai kompensasi yang dapat diberikan oleh pemerintah Belanda, tidak setiap kerugian yang timbul dari pelanggaran memenuhi syarat untuk

${ }^{19}$ Kyodo, "Mainali Eyes Wrongful Imprisonment Suit Against Japan," Japan Times, 2013.

${ }^{20}$ Kana Sasakura, "Compensation for the Wrongfully Convicted."

${ }^{21}$ Peter J.P. Tak, The Dutch Criminal Justice System (Wolf Legal Publishers, 2008). mendapatkan kompensasi. Kompensasi ini hanya diberikan pada kerugian akibat cedera atau kematian. Selain itu juga, dana kompensasi pelanggaran kekerasan juga tidak mengkompensasi seluruh kerugian, tetapi hanya untuk melakukan pembayaran penyembuhan berdasarkan prinsip kewajaran dan juga keadilan. Ada dua jenis kerugian yang dimaksud yaitu kerugian material dan kesulitan. Kerugian material menyebabkan kerugian finansial yaitu biaya yang terjadi atau yang harus dikeluarkan dan pendapatan yang hilang. Contohnya adalah biaya dokter, pakaian rusak, tagihan rumah sakit, kehilangan kapasitas untuk bekerja, dan lain lain. Kesengsaraan berarti kehilangan atau gangguan sementara dalam kenikmatan hidup. ${ }^{22}$

Permohonan untuk mengajukan kompensasi harus diajukan dalam waktu tiga tahun sejak tanggal terjadinya pelanggaran tersebut. Jika pihak yang dirugikan tidak dapat secara wajar mengajukan permohonan dalam waktu tersebut, maka aplikasi tersebut masih akan diproses. Mengenai jumlah minimum dan maksimum yang dapat diberikan untuk kompensasi, mulai 1 Januari 2003 aturan yang ditetapkan adalah sebagai berikut:

1. Pembayaran maksimum adalah $€ 22.700$ untuk kerugian materi;

2. Pembayaran maksimum adalah $€ 9.100$ untuk kesulitan;

3. Pembayaran minimum untuk marabahaya adalah $€ 454$;

4. Pembayaran rata rata adalah $€ 2.723$ (dibulatkan menjadi $€ 908$ untuk kerugian materi dan $€ 1.815$ untuk kesulitan).

\section{Inggris}

Pada April 2006, Pemerintah menjalankan dua bentuk kompensasi untuk korban kesalahan hukum di Inggris yaitu skema diskresioner dan skema hukum. Namun, skema diskresioner telah dihapuskan. Skema diskresioner memberikan kekuasaan kepada Sekretaris Kehakiman untuk membayar orang yang telah salah dihukum "ketika putusannya dibatalkan atau dia diampuni dengan alasan bahwa fakta baru atau

\footnotetext{
${ }^{22}$ European Judicial Network, "Compensation to Crime Victims," https://ec.europa.eu/ civiljustice/comp_crime_victim/comp_crime_victim _net_en.htm\#1.1.
} 
yang baru ditemukan menunjukkan tanpa keraguan bahwa telah ada keguguran keadilan”.

Skema diskresioner memberikan kompensasi kepada orang yang memenuhi kriteria:

1. Orang tersebut telah menerima grasi atau hukumannya dibatalkan oleh Pengadilan Tinggi atau House of Lords setelah referensi di bawah Pasal 17 Criminal Appeal Act 1968 atau banding telah melewati batas waktu;

2. Masa tahanannya dan tuduhannya yang salah karena hasil dari kesalahan polisi atau otoritas publik lain;

3. Kasusnya melibatkan keadaan luar biasa, misalnya masa persidangan atau banding telah selesai dan baru ditemukan fakta lain. ${ }^{23}$

Pada tahun 2011, Mahkamah Agung memutuskan bahwa arti "keguguran keadilan" pada tujuan skema diskresioner tidak hanya terbatas pada tersangka yang dapat membuktikan bahwa mereka bersalah. Sebaliknya, harus diperluas ke kasus-kasus dimana fakta baru atau baru ditemukan "sangat merusak bukti terhadap terdakwa sehingga tidak ada putusan bersalah yang dapat dijatuhkan kepadanya".

Jika Sekretaris Negara memutuskan bahwa seorang tersangka salah tangkap memenuhi syarat untuk mendapatkan kompensasi berdasarkan Pasal 133, jumlah kompensasi yang diberikan akan ditentukan oleh penilai independen. Jumlah maksimum kompensasi yang dapat diberikan adalah $€ 1$ juta dalam kasus dimana pemohon telah dipenjara setidaknya 10 tahun, atau $€ 500,000$ untuk semua kasus. ${ }^{24}$

Pasal 133 dalam Criminal Justice Act 1988, menyatakan bahwa:

"When a person has been convicted of a criminal offence and when subsequently his conviction has been reversed or he has been pardoned on the ground that a new or newly discovered fact shows beyond reasonable doubt that there has been a miscarriage of justice, the Secretary of State shall pay

\footnotetext{
${ }^{23}$ HC Deb, "Compensation” (UK Parliament, 1985).

24 Sally Lipscombe and Jacquaeline Beard, "Miscarriages of Justice: Compensation Schemes," House of Commons Library, 2015.
}

compensation for the miscarriage of justice to the person who has suffered punishment as a result of such conviction or, if he is dead, to his personal representatives, unless the non-disclosure of the unknown fact was wholly or partly attributable to the person convicted."

Kendala dalam pelaksanaan masalah pembayaran ganti kerugian tersebut. Apabila pihak korban tetap menuntut ganti kerugian yang bersifat immateriil juga, hasilnya akan nihil, karena putusan selalu menyatakan: gugatan ganti kerugian immateriil tersebut dinayatakan tidak dapat diterima, kerena tidak berdasarkan hukum, karena gugatan ganti kerugian pada perkara pidana hanya bersifat assessor. ${ }^{25} \mathrm{Hal}$ inilah yang harus menjadi perhatian bersama oleh para penegak hukum dalam melaksanakan pembayaran ganti kerugian, karena kebanyakan korban juga mengajukan kerugian immaterial dalam tuntutannya.

\section{KESIMPULAN}

Simpulan dari hasil kajian ini bahwa tata cara eksekusi ganti kerugian dapat dilakukan dengan beberapa hal sebagai berikut: yang pertama, pengadilan dapat langsung memutus, ganti kerugian tanpa adanya tuntutan terlebih dahulu dari tersangka, terdakwa atau terpidana yang ditangkap, ditahan, dituntut dan diadili atau dikenakan tindakan lain, tanpa alasan yang berdasarkan undang-undang atau karena kekeliruan mengenai orangnya atau hukum yang diterapkan. Kedua, dalam hal terdapat kerugian, putusan pengadilan pidana harus sekaligus mencantumkan ganti kerugiannya. Sebagai putusan pengadilan, apabila telah berkekuatan hukum tetap maka negara dalam hal ini Jaksa Penuntut Umum (JPU) sebagai eksekutor segera menjalankannya. Ketiga, dalam hal pelanggaran prosedur penegakan hukum, baik yang masuk ke ranah hukum pidana maupun sekedar pelanggaran prosedur, diperlukan suatu keputusan hukum untuk menjadi dasar dijatuhkannya ganti kerugian. Atas dasar itulah

25 Al Munawwar Tsabit Aqyl, "Implementasi Penggabungan Perkara Gugatan GantiKerugian Dalam Penyelesaian Perkara Pidana (Studi Kasus Di Kejaksaan Negeri Surakarta)" (Universitas Muhammadiyah Surakarta, n.d.). 
timbulnya kewajiban negara untuk memberikan ganti kerugian. Keputusan hukum, baik berupa suatu penetapan, putusan pengadilan, dan atau bentuk lainnya, harus bersifat final dan mengikat sehingga tidak diperlukan lagi upaya hukum apapun untuk menjalankannya kecuali sekedar ketentuan dan syarat administrasi sehubungan dengan birokrasi. Keempat, mekanisme ganti kerugian korban karena ditangkap, ditahan, dituntut dan diadili atau dikenakan tindakan lain, tanpa alasan yang berdasarkan undang-undang atau karena kekeliruan, dapat dilakukan melalui penyelesaian sengketa di luar pengadilan (non litigasi), yang lazim dinamakan dengan Alternative Dispute Resolution (ADR). Kelima, pejabat yang karena kesalahan, kealpaan atau kelalaiannya mengakibatkan negara harus membayar ganti kerugian, dapat dikenakan tindakan sesuai dengan peraturan yang berlaku.

\section{SARAN}

Saran yang disampaikan dari hasil kajian ini pertama, mengingat kebanyakan korban yang menjadi salah tangkap ini adalah orang-orang kecil/masyarakat biasa yang kurang paham mengenai proses hukum/peradilan pidana, apalagi terkait hak-haknya yang menyangkut ganti rugi sehingga perlu dipermudah untuk pemberian ganti kerugiannya, asalkan sudah dibuktikan kerugian tersebut, oleh karena itu proses ganti kerugian ini lebih baik melalui proses yang cepat. Oleh karena itu hakim perlu menetapkan besaran kerugian yang harus dibayarkan oleh Negara kepada korban salah tangkap/salah prosedur tersebut, sehingga korban tidak perlu lagi mengajukan gugatan ganti kerugian. Kedua, Mekanisme pembayaran ganti kerugian, tetap harus dibayarkan melalui Kementerian Keuangan, agar lebih netral, karena Kementerian Keuangan bukan bagian dari lembaga penegak hukum. Terkait hal ini, Kementerian Keuangan perlu membuat pedoman dalam rangka mempercepat proses pencairan ganti kerugian. Karena pedoman/aturan yang ada saat ini masih menggunakan Peraturan Menteri Keuangan Nomor 983/KMK.01/1983. Alternative lainnya Kementerian Keuangan dapat memberikan anggaran kepada pengadilan negeri untuk pencairan ganti kerugian, sehingga korban dapat langsung menerima haknya.

\section{UCAPAN TERIMA KASIH}

Terima kasih penulis ucapkan kepada Kepala Pusat Penelitian dan Pengembangan Hukum yang telah memberikan kesempatan kepada penulis untuk melakukan kajian ini. Semoga kajian ini dapat dijadikan bahan untuk kemajuan hukum pidana di Indonesia, khususnya mengenai tata cara eksekusi ganti kerugian dalam perkara pidana.

\section{DAFTAR KEPUSTAKAAN}

Aqyl, Al Munawwar Tsabit. "Implementasi Penggabungan Perkara Gugatan GantiKerugian Dalam Penyelesaian Perkara Pidana (Studi Kasus Di Kejaksaan Negeri Surakarta)." Universitas Muhammadiyah Surakarta, n.d.

Ariani, Nevey Varida. "Gugatan Sederhana Dalam Sistem Peradilan Pidana Di Indonesia." $D E$ JURE 18 (2018): 381-396.

Cabinet, Prime Minister of Japan and his. The Constitution of Japan, 1947. https://japan.kantei.go.jp/constitution_and_g overnment_of_japan/constitution_e.html.

Deb, HC. “Compensation.” UK Parliament, 1985.

Haqulana, Mewan. "Kisah Korban Salah Tangkap, Dua Kaki Didor Oknum Polisi Sampai Pasrah Ingin Mati." Okezone.

Keneally, Meghan. "Will the State Pay You for a Wrongful Conviction?" https://abcnews.go.com/US/state-paywrongful-conviction-dependsstate/story? $\mathrm{id}=62436623$.

Kyodo. "Mainali Eyes Wrongful Imprisonment Suit Against Japan.” Japan Times, 2013.

Lipscombe, Sally, and Jacquaeline Beard. "Miscarriages of Justice: Compensation Schemes." House of Commons Library, 2015.

Mulyadi, Lilik. Putusan Hakim Dalam Hukum Acara Pidana. Bandung: Citra Aditya Bakti, 2007.

Nawawi, Hadari. Metode Penelitian Sosial. Yogyakarta: Gajahmada Press, 1993.

Network, European Judicial. "Compensation to Crime Victims." https://ec.europa.eu/ civiljustice/comp_crime_victim/comp_crime _victim_net_en.htm\#1.1. 
Puspita, Sherly. "Kisah Korban Salah Tangkap Yang Disiksa Polisi." Kompas.Com.

Quick, Hannah, and Marny Requa. "The Supreme Court on Compensation for Miscarriages of Justice: Is It Better That Ten Innocents Are Denied Compensation than One Guilty Person Receives It?" The Modern Law Review $\quad 75$ (2012): 387-400. //www.jstor.org/stable/41682857.

Republik Indonesia. Undang-Undang Nomor 8 Tahun 1981 Tentang Hukum Acara Pidana, 1981.

Saputra, Andi. "Ganti Rugi Tak Kunjung Cair, Korban Salah Tangkap Gugat Menkeu." DetikNews.

Sasakura, Kana. "Compensation for the Wrongfully Convicted."

Sinaga, Dahlan. Kemandirian Dan Kebebasan Hakim Memutus Perkara Pidana Dalam Negara Hukum Pancasila, Suatu Perspektif Teori Keadilan Bermartabat. Bandung: Nusa Media, 2015.

Sudaryanto, Agus. Pengantar Ilmu Hukum, Pengertian Dan Perkembangannya Di Indonesia. Malang: Setara Press, 2015.

Sutatiek, Sri. Menyoal Akuntabilitas Moral Hakim Pidana Dalam Memeriksa, Mengadili, Dan Memutus Perkara. Yogyakarta: Aswaja, 2013.

Syafruddin. Pidana Ganti Rugi: Alternatif Pemidanaan Di Masa Depan Dalam
Penanggulangan Kejahatan Tertentu. Medan: Universitas Sumatera Utara, 2002.

Tak, Peter J.P. The Dutch Criminal Justice System. Wolf Legal Publishers, 2008.

Tampi, Butje. "KUHAP Dan Pengaturan Ganti RugiPihak Korban Dalam Perkara Pidana." Vol.II/No.2/Januari-Maret $12014 \quad$ Edisi Khusus II (2014): 24-35.

Utama, Abraham. "Kisah Kuswanto, Korban Salah Tangkap Yang Dibakar Polisi." Cnn Indonesia. Last modified 2015. Accessed January 25, 2018. https://www.cnnindonesia.com/nasional/201 50626090000-32-62513/kisah-kuswantokorban-salah-tangkap-yang-dibakar-polisi.

Veronika, Flora. "Penerapan Ganti Kerugian Terhadap Terdakwa Yang Diputus Bebas Berdasarkan Kitab Undang-Undang Hukum Acara Pidana Di Pengadilan Negeri Pekanbaru." JOM Fakultas Hukum Volume III Nomor 1, Februari 2016. III (2016): 116.

Prancis, Protocol No.7 to the Convention for the Protection of Human Rights and Fundamental Freedoms. Perancis, 1984.

Veronika, Flora, Penerapan Ganti Kerugian Terhadap Terdakwa yang Diputus Bebas Berdasarkan Kitab Undang-Undang Hukum Acara Pidana di Pengadilan Negeri Pekanbaru, JOM Fakultas Hukum Volume III Nomor 1, Februari 2016 